\title{
Evapotranspiration from Remote Sensing to Improve the Swat Model in Eastern Amazonia
}

\author{
Adriano Marlison Leão de Sousa ${ }^{1}$, Maria Isabel Vitorino ${ }^{2}$, Nilza Maria dos Reis Castro ${ }^{3}$, \\ Marcel do Nascimento Botelho ${ }^{1}$, Paulo Jorge Oliveira Ponte de Souza ${ }^{1}$ \\ ${ }^{1}$ Instituto Socioambiental e dos Recursos Hidricos, Universidade Federal Rural da Amazônia - UFRA, \\ Belém/PA, Brasil \\ ${ }^{2}$ Programa de Pós-Graduação em Ciências Ambientais, Faculdade de Meteorologia, \\ Universidade Federal do Pará - UFPA, Belém/PA, Brasil \\ ${ }^{3}$ Instituto de Pesquisas Hidráulicas - IPH, Universidade Federal do Rio Grande do Sul - UFRGS, \\ Porto Alegre/RS, Brasil
}

\begin{abstract}
In this study, we estimated the evapotranspiration from orbital images - MODIS (Moderate Resolution Imaging Spectroradiometer) for assimilation in the hydrological modeling of the SWAT (Soil Water Assessment Tools) model. The data used include the period between October 2003 and December 2006 of the sub-basin of the Lajeado River, located in the Tocantins-Araguaia River basin in Tocantins state. Overall, the results of the use of heat flows estimated by remote sensors in the SWAT model can be considered satisfactory. The values of the COE (coefficient of efficiency of Nash-Sutcliffe) ranged from - 0.40 to 0.91 in the comparison with the daily flow data and from 0.17 to 0.77 with the monthly flow data, with the assimilation of evapotranspiration from orbital images. These results indicate benefit to the model adjustment due to improvement in the data assimilated of approximately 0.91 in the COE on daily scale and 0.60 in the CEO on monthly scale.
\end{abstract}

Keywords: MODIS, hydrology, modeling.

\section{Evapotranspiração a partir de Sensoriamento Remoto para Assimilação no Modelo Swat no Leste da Amazônia}

\section{RESUMO}

Neste estudo estimou-se a evapotranspiração a partir de imagens orbitais MODIS (Moderate Resolution Imaging Spectroradiometer) para assimilação na modelagem hidrológica do modelo SWAT (Soil Water Assessment Tools). Os dados utilizados compreendem o período de outubro de 2003 a dezembro de 2006 da sub-bacia do rio Lajeado, localizada na bacia do rio Tocantins-Araguaia, no estado do Tocantins. No geral, os resultados da utilização dos fluxos de calor estimados por sensores remotos no modelo SWAT podem ser julgados satisfatórios. Os valores de COE (Coefficient of Efficiency of Nash-Sutcliffe) variaram de -0,40 para 0,91 na comparação dos dados diários de vazão e de 0,17 para 0,77 com os dados mensais de vazão, com a assimilação da evapotranspiração a partir de imagens orbitais. Isso indica benefício no ajuste do modelo, devido a uma melhoria nos dados assimilados de aproximadamente 0,91 no COE na escala diária e de 0,60 na escala mensal.

Palavras-chave: MODIS, hidrologia, modelagem. 


\section{INTRODUCTION}

Improving the accuracy of forecasts of ungauged basins is one of the most challenging tasks in hydrology (Lévesque et al., 2014; Oliveira, 2014; Franks et al., 2005; Goswami et al., 2007; Sivapalan et al., 2003; Zhang et al., 2009). Several researchers have used remote sensing data to better represent the spatial variations of the surface, and there are several that we can highlight. Andersen et al. (2002) used data on leaf area index (LAI) derived from the Advanced Very High Resolution Radiometer (AVHRR) in a distributed hydrologic model and found that LAI can better represent the spatial heterogeneity of plant surface in the simulations of the model in the river basin of Senegal. Garcia-Quijano \& Barros (2005) and Gebremichael \& Barros (2006) used satellite images to estimate LAI in order to assimilate into a distributed hydrological model, which showed that the daily variation of evaporation and photosynthesis can be captured by the interaction of biophysical and hydrological processes. Zhang \& Wegehenkel (2006) added data from remote sensing of LAI in a model of water balance and found a strong control of the LAI seasonal evapotranspiration and runoff in a watershed in Germany. McMichael et al. (2006) showed that the LAI using remote sensing in distributed hydrological modeling can reduce the uncertainty of estimates of flow in a watershed in the semi-arid region of California-USA. Yildiz \& Barros (2007) used data of LAI estimated from orbital images in hydrologic models and found that vegetation plays a key role in control of hydrological processes in a catchment area of mid-latitudes.

More recently, Zhang et al. (2009) showed that the use of evapotranspiration estimations from remote sensing applied to the calibration of hydrologic model SIMHYD can improve the modeling daily and monthly ungauged catchment. This demonstrates that the calibration using the evapotranspiration estimated and observed flow improves the results of hydrologic modeling.

In this context, the objective of this study is to estimate evapotranspiration (ETrs) for the tropical region, specifically in the eastern Amazon, from orbital images for use in hydrologic modeling. For this we used the SEBAL model (Surface Energy Balance
Algorithms for Land - Bastiaanssena et al., 1998) to generate input information from the hydrologic model SWAT (Soil Water Assessment Tools) to simulate the water balance in the Lajeado River basin in the state of Tocantins, Brazil. It is worth to be mentioned that only few published works address sensing data assimilated in SWAT model, such as Immerzeel et al. (2008) and Immerzeel \& Droogers (2008).

\section{DATA AND METHODOLOGY}

\subsection{Study area}

This study was developed in eastern Amazonia in the years 2004 and 2005 (presented). The area of interest for the study is located in the Lajeado basin Figure 1. The data used in this work are from the experimental site "Bananal Island Floodplain" (BIF); these were collected at the north side of the island near the boundaries with the Cantão State Park, with the installation of a 40-meter tall micrometeorological tower, located approximately $2 \mathrm{~km}$ east of Javaezinho river, at coordinates $9.824^{\circ} \mathrm{S}, 50.158^{\circ} \mathrm{W}$, and altitude $120 \mathrm{~m}$ Figure 1.

\subsection{Observational meteorological data}

The rainfall and Stream flow data used in this work are the stations (code): Piranhas River (949000), Marianopolis (949003), Caseara (950000) and river Javaés (950002) and Ponte Piranha River (27380000) for the period 2000 to 2008 (observational data) measured in the watershed area and made available by the National Water Agency (ANA, 2013).

The observational data are part of the project of large-scale Biosphere-atmosphere in Amazon (LBA). Micrometeorological measurements (hourly and daily) of flows of energy (latent and sensible heat), concentration of water vapor and the basic meteorological variables (air temperature, radiation balance, wind speed and soil heat flux), were obtained through conventional sensors and eddy correlation, respectively.

\subsection{MODIS time series data}

To construct the daily series of ETrs, images were used of MODIS of Aqua satellite (Kaufman et al., 1998), passing at 13:30 local time, with spatial resolution of $250 \mathrm{~m}$ (surface reflectance), $500 \mathrm{~m}$ (NDVI - Normalized 


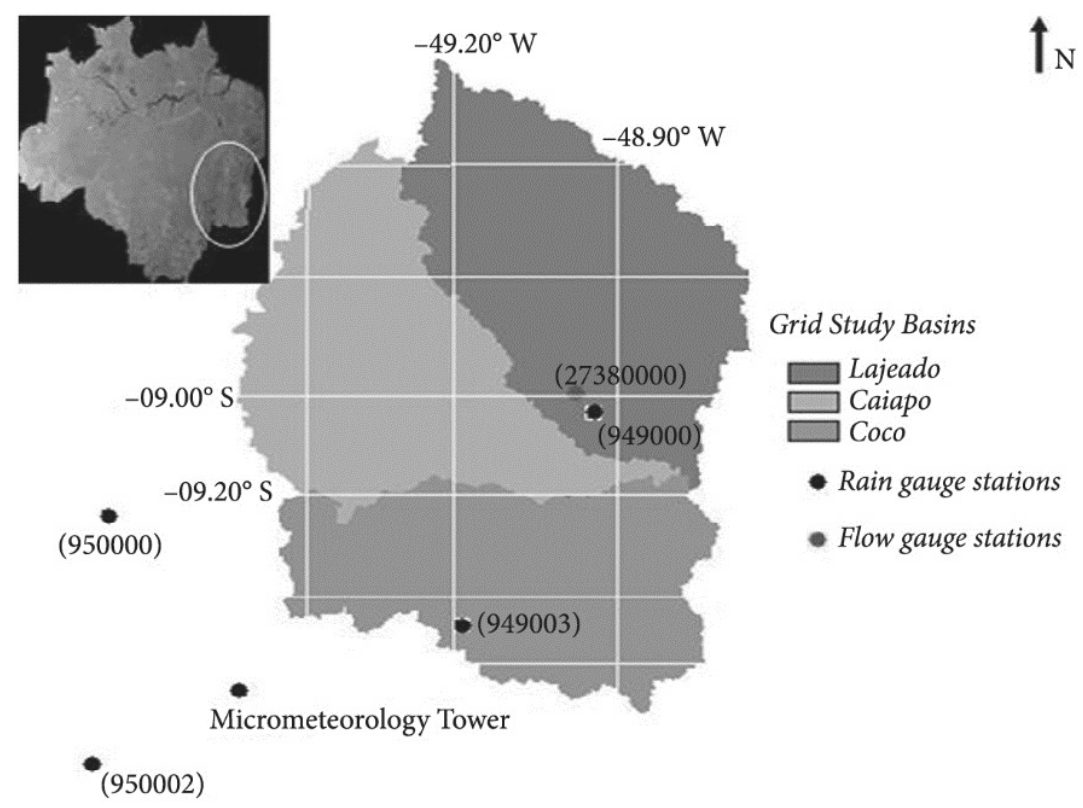

Figure 1. Map of sub-basins and rain gauge stations and gauged the study area.

Figura 1. Mapa das sub bacias e estações de precipitação na área de estudo.

difference vegetation index) and surface temperature at $1000 \mathrm{~m}$ for 2004 and 2005 in grid $2^{\circ} \times 2^{\circ}$ in the limits of $50^{\circ}$ to $48^{\circ} \mathrm{W}$ and $10^{\circ}$ to $08^{\circ} \mathrm{S}$.

\subsection{Evapotranspiration and streamflow models}

The evapotranspiration estimation by SEBAL needs little information from the surface to estimate the components of energy balance through remote sensing. The ETrs is obtained as the residue of the equation of energy balance. Equation 1 presents the premise of the energy balance model, and SEBAL details may be seen in (Bastiaanssen et al., 1998).

$\lambda E T=R_{n}-H-G$

Where: $\lambda \mathrm{ET}$ - is the evapotranspiration $\left(\mathrm{W} \mathrm{m}^{-2}\right)$, $\mathrm{Rn}$ - is net radiation at the surface $\left(\mathrm{W} \mathrm{m}^{-2}\right), \mathrm{H}$ - is the sensible heat flux $\left(\mathrm{W} \mathrm{m}^{-2}\right)$ and $\mathrm{G}$ - is the flow of heat to the soil $\left(\mathrm{W} \mathrm{m}^{-2}\right)$.

Equation 2 becomes latent heat $\lambda \mathrm{ET}$ instant estimated by SEBAL at the time of passage of the satellite in $\mathrm{W} / \mathrm{m}^{-2}$, ET time $\left(\mathrm{ET}_{\text {hourly }}\right)$ in $\mathrm{mm} / \mathrm{hr}$.

$E T_{\text {hourly }}=3600 \times \frac{\lambda E T}{\lambda}$

where; $\mathrm{ET}_{\text {hourly }}$ is the hourly $\mathrm{ET}(\mathrm{mm} / \mathrm{hr}), 3600$ is the time conversion from seconds to hours, and $\lambda$ is the latent heat of vaporization or the heat absorbed when a kilogram of water evaporates $(\mathrm{J} / \mathrm{kg})$.

Later the Equation 3, the Reference ET Fraction $\left(\mathrm{ET}_{\mathrm{rF}}\right)$ is defined as the ratio of the computed hourly ET $\left(\mathrm{ET}_{\text {hourly }}\right)$ for each pixel to the reference $\mathrm{ET}\left(\mathrm{ET}_{\mathrm{r}_{-} \text {hourly }}\right)$ computed from weather data:

$E \operatorname{Tr} F=\frac{E T_{\text {hourly }}}{E T_{r_{-} \text {hourly }}}$

where; $\mathrm{ET}_{\text {hourly }}$ is from Equation $2(\mathrm{~mm} / \mathrm{hr})$ and $\mathrm{ET}_{\mathrm{r} \_ \text {hourly }}$ is the reference ET at the time of the image from the REF-ET software $(\mathrm{mm} / \mathrm{hr})$. $\mathrm{ET}_{\mathrm{rE}}$ is similar to the well-known crop coefficient, $\mathrm{Kc}$. $\mathrm{ET}_{\mathrm{rF}}$ is used to extrapolate ET from the image time to 24-hour or longer periods. The transformation to the daily range follows the equation (Equation 4):

$E T_{24}=E \operatorname{Tr} F \times E T_{r-24 h}$

where; $\mathrm{ET}_{\mathrm{r}-24}$ is the cumulative 24-hour ETr for the day of the image. This is calculated by adding the hourly ETr values over the day of the image.

The hydrological cycle simulated by SWAT is composed of four control volumes: (i) surface reservoir, (ii) subsurface reservoir, (iii) underground storage tank - free or shallow aquifer and (iv) underground storage tank - deep aquifer. The contributions from these reservoirs to runoff come from the lateral flow from 
the soil profile and the return flow of shallow aquifer. The volume of the reservoir that percolates through the subsurface soil profile represents the shallow aquifer recharge. The water that percolates to the deep aquifer does not return to the system. In the SWAT model, the determination of the production of surface water basin is based on the water balance, equation (Equation 5) details may be seen in (Arnold et al., 1996).

$$
S W_{t}=S W+\sum_{i=1}^{t}\left(R_{i}-Q_{i}-E T_{i}-P_{i}-q_{\text {lati }}-q_{r i}\right)
$$

Where SWt - is the amount of water in the ground on $\mathrm{t}, \mathrm{SW}$ - is the initial amount of soil water in $\mathrm{mm}$, $\mathrm{R}$ - is the daily rainfall in $\mathrm{mm}, \mathrm{Q}$ - is runoff in $\mathrm{mm}$, ET - is evapotranspiration in $\mathrm{mm}, \mathrm{P}$ - is the percolation in $\mathrm{mm}, \mathrm{q}_{\text {lat }}$ - is the lateral flow in $\mathrm{mm}, \mathrm{q}_{\mathrm{r}}$ - is the return flow, and $\mathrm{mm}$ is the time in days.

\subsection{Modeling experiments}

Conceptually SWAT subdivides the catchment into sub-basins and a river network based on a digital elevation model (DEM). Based on unique combinations of soil and land use, the sub-basins were further detailed into hydrological response units (HRUs), which were the fundamental units of calculation. A total of 23 sub-basins and 525 HRUs were delineated in the study area.

The simulation scenario consisted of two numerical experiments in order to verify the improved efficiency and applicability of the SWAT model to assimilate the ETrs extracted from remote sensing (in daily scale). It is worth mentioning, that all meteorological data inserted into SWAT followed the daily time scale.

\subsection{Experiment 1 - contours initial calibration}

Experiment 1 was used to select the "default" model, where the weather data were used for the initial condition required to represent physically the location of study. This experiment was the basis for the others, due to its simplicity and effectiveness in representing the initial conditions of the study area. After the first experiment, it was how the model was able to reproduce the observed flow using the statistical tools.

\subsection{Experiment 2 - manual calibration with}

evapotranspiration (ETrs)

For the second numerical experiment, the tuning parameters of the model were no longer modified, and therefore, preceded to the assimilation of data evapotranspiration estimated by the model SEBAL from orbital images.

\subsection{Model assessment}

The verification phase of the SWAT model is essential for assessing the performance of the simulation, and therefore the operational use in the management of water resources. The performance of the model was obtained from the observed and simulated values, calculated using the following statistical methods: the coefficient of efficiency of Nash-Sutcliffe (COE) and the correlation between predicted and observed streamflow (CORR), with $10 \%$ confidence interval around the absolute error.

The COE can vary from less infinity to 1 (Nash \& Sutcliffe, 1970), with 1 indicating the perfect simulation of the simulated event (Equation 6):

$C O E=1-\frac{\sum_{i=1}^{n}\left(E_{o b}-E_{c a l}\right)^{2}}{\sum_{i=1}^{n}\left(E_{o b}-E_{m}\right)^{2}}$

Where $\mathrm{E}_{\mathrm{cal}}$ and $\mathrm{E}_{\mathrm{ob}}$ - are the simulated runoff and observed stream flow respectively, $\mathrm{E}_{\mathrm{m}}$ - is the arithmetic mean of the observed runoff, and $\mathrm{N}$ - is the number of samples.

\section{RESULTS AND DISCUSSION}

Having calibrated the model with data for the period 2000 to 2003, the first simulation of the monthly and daily streamflow was tested for the years 2004 and 2005, using the calibration with the initial contours. In general, the SWAT model overestimated the peak streamflow rates, possibly because the model is generating very of base flow and low evaporation.

\subsection{Experiment 1 - contours initial calibration}

After viewing the initial results, we can highlight the difficulty of the SWAT model in the peak discharge and flow basis. For daily values, the peak flows were overestimated, while in the dry season, the simulated 
values were very close to those observed. There was a slight delay in the responses of the model, especially at the end of the rainy season. This may be associated with delayed observation of rain in the region with respect to the measurement section Figure 2a. The results in the monthly basis show that the model simulated the seasonal variation, although overestimating the volume of runoff compared with observed values for the runoff model could answer a few rain events Figure $2 b$.

\subsection{Experiment 2 - manual calibration with evapotranspiration (ETrs)}

In general, we can highlight a considered and significant improvement in total flow (about 10\%) after the assimilation of the ETrs. Moreover, to emphasize that this flow simulation underestimates the observed stream flow.

In Figure 3, one can observe that there is a decrease in overestimation of the maximum streamflow.


(b)

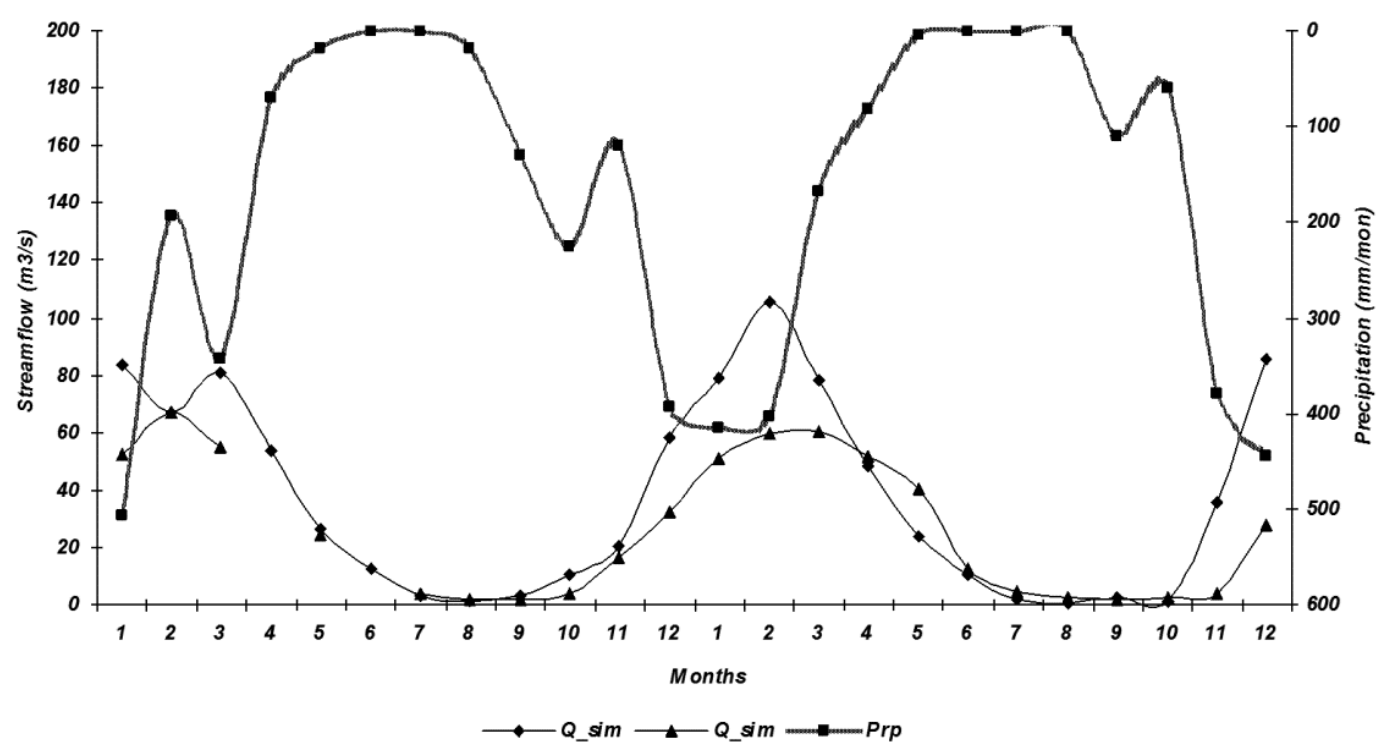

Figure 2. Comparison between simulated and observed runoff (Exp.1), (a) daily and (b) monthly. Figura 2. Comparação da vazão simulado e observado (Exp. 1), (a) diário e (b) mensal. 
(a)

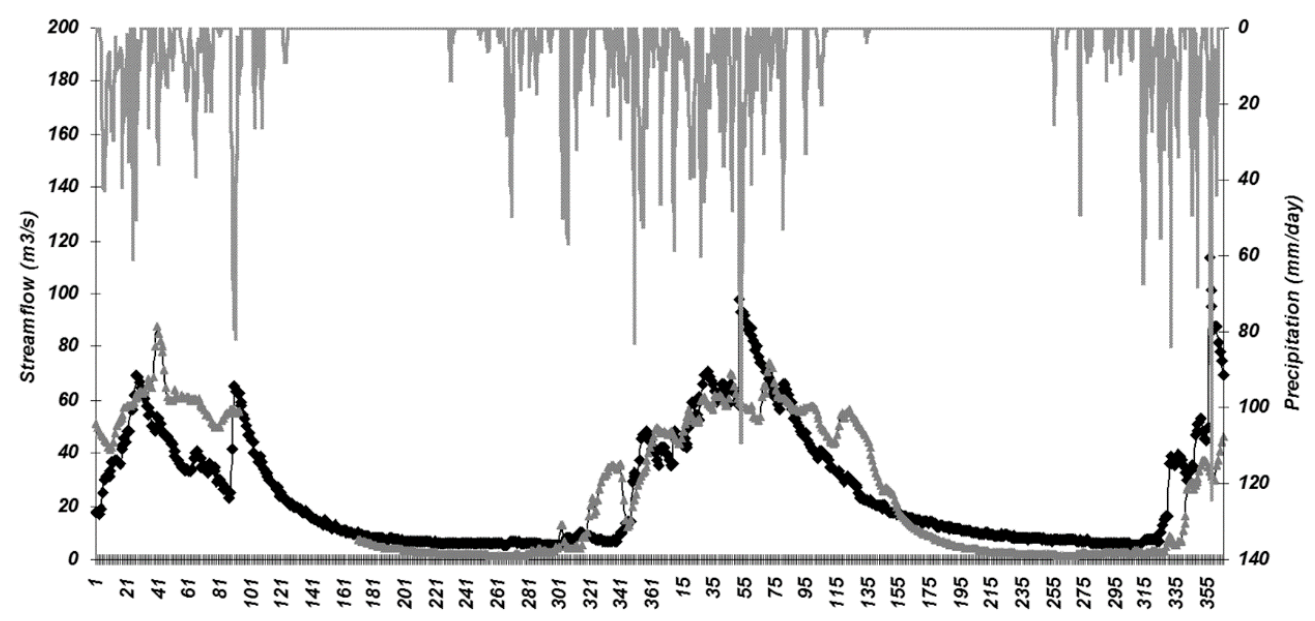

$\longrightarrow$ Q_sim $\stackrel{\text { Days }}{\longleftarrow}$ Q_obs $\longrightarrow$ prp

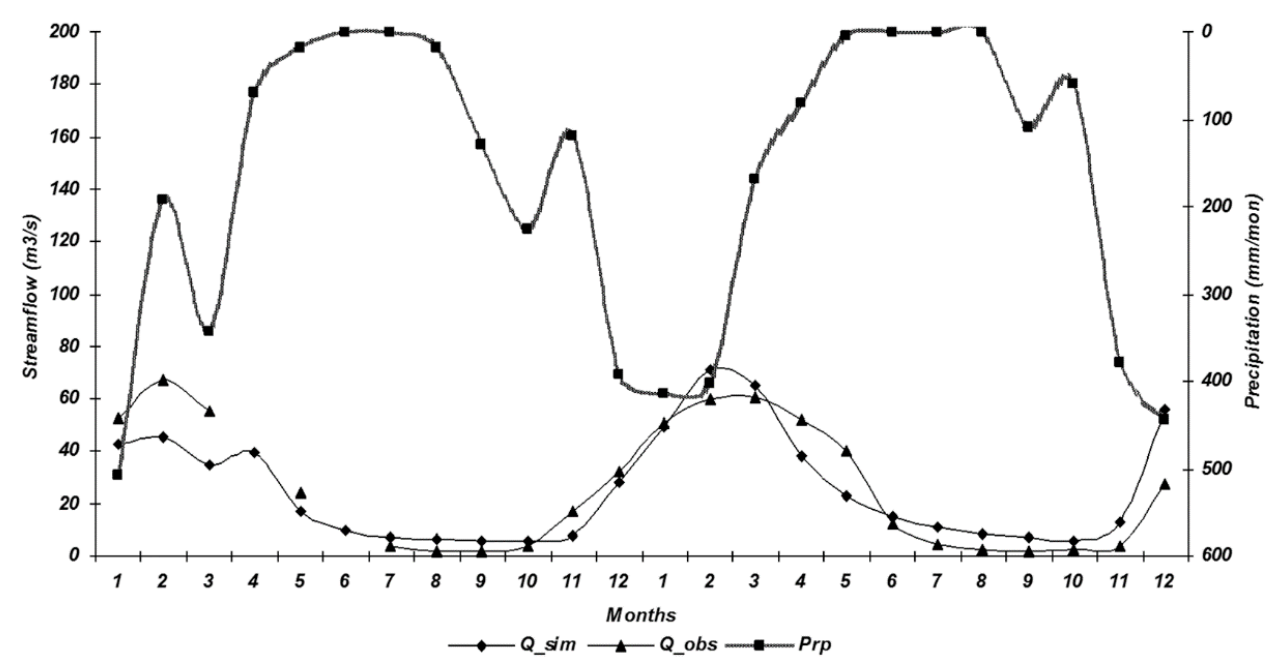

Figure 3. Comparison between simulated and observed runoff (Exp.2), a) daily and b) monthly.

Figura 3. Comparação da vazão simulada e observada (Exp. 2), a) diário e b) mensal.

The minimum flow simulated reaching close to zero, obtained a significant improvement compared with the observed streamflow. By comparison of results between experiments, it appears that the results with the uptake of ETrs are relatively acceptable, where the simulated flow underestimates the observed flow in percentages lower than $10 \%$.

\subsection{Assessment of the efficiency experiments}

The development of results in the performance verification of the model in the experiments, show that the comparison of daily data resulted in a coefficient of efficiency (COE) from -0.40 in Exp. 1, after the assimilation of the value ETrs of (COE) increased to 0.91 Exp. 2, showing a significant improvement in results of $9.000 \mathrm{~m}^{3} \mathrm{~s}^{-1}$ to deficit of $800 \mathrm{~m}^{3} \mathrm{~s}^{-1}$, respectively. The monthly results also showed that after the assimilation of the ETrs, the (COE) increased from 0.17 to 0.77 , which improved results of deficit $311 \mathrm{~m}^{3} \mathrm{~s}^{-1}$ to less negative of $62 \mathrm{~m}^{3} \mathrm{~s}^{-1}$, respectively.

The results indicate that the use of ETrs Exp. 2, can improve the estimated daily and monthly runoff in ungauged catchments. They also showed good agreement between the modelled mean runoff and 
observed mean runoff in Exp. 2 compared to Exp. 1 Figure 4, with standard deviation less than $10 \%$, in the comparison of the results shortly after the assimilation of ETrs.

Liew \& Garbrecht (2003) applied the SWAT model in the southwestern state of Oklahoma (USA) at different times and also showed different values for each period. During the dry season COE was 0.65, whereas in the rainy season it was 0.45 . Andersen et al. (2002) and later McMichael et al. (2006) demonstrated how important role is the control of vegetation in the water cycle, mainly

(a)



(C)



because it affects the interception, evapotranspiration and water dynamics in soil. Through the use of remote sensing in the plant, forcing it was shown by the characteristics of property plant and ultimately improving the numerical results. Finally, Zhang et al. (2009) showed that the vegetation data extracted from remote sensing can be used for computation of actual evapotranspiration as well as other components of water balance and energy balance.

It is interesting to comment that the results obtained in this study are consistent with those found by other authors

(b)



(d)

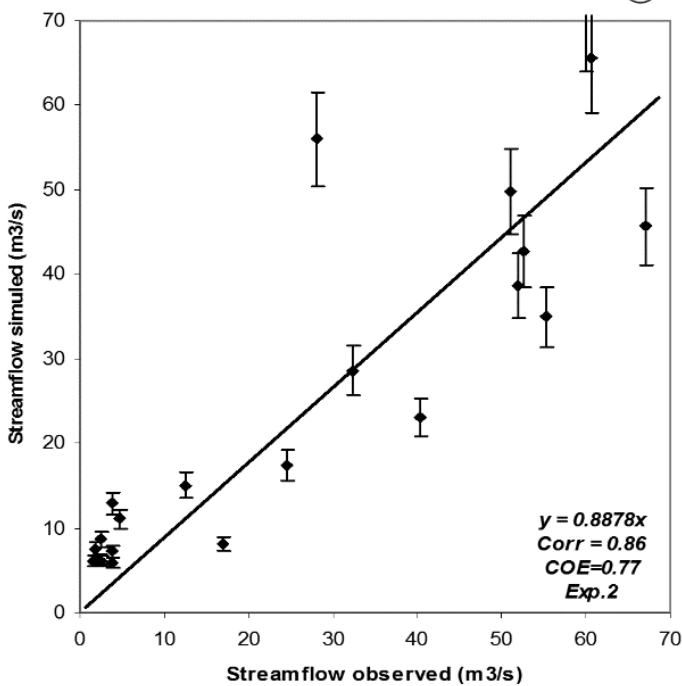

Figure 4. Simulated runoff from the modeling experiments versus observed runoff, a) daily (Exp. 1), b) monthly (Exp. 1), c) daily (Exp. 2), d) monthly (Exp. 2).

Figura 4. Vazão simulada versus vazão observada, a) diário (Exp. 1), b) mensal (Exp. 1), c) diário (Exp. 2), d) mensal (Exp. 2). 
(Setegn et al., 2010; Liew \& Garbrecht, 2003; Machado et al., 2003; Baldissera, 2005; Paiva \& Paiva, 2006; Lubitz, 2009). Although the general features of the results obtained in this work are common to other cases discussed in the literature, there are peculiarities of each case.

\section{CONCLUSION}

In general, the estimated ETrs data from remote sensors and integrated into the SWAT model significantly improved the numerical simulations of streamflow in the ungauged catchments thus demonstrating the wide applicability of remote sensing data for the prediction of flow in a distributed model composed of combined physical soil-plant-atmosphere led to more realistic results of the study area. Even so, the findings of this study show that the use of spectral information from remote sensors of moderate spatial resolution can provide estimates of heat fluxes at the surface and spatial evapotranspiration consistent with use and land cover for assimilation into hydrology models.

The COE values, used as main index template efficiency assessment, were above $0.85 \%$ in comparison of daily data and monthly streamflow, after the assimilation of ETrs, indicating a good adjustment. Comparison of daily data that produced the best results was partly explained by the incoming data (with hourly frequency, flawless records). Other problems such as the inability to reproduce the spatial distribution of rainfall or obtaining data from more meteorological stations around the basin, may have contributed to the decrease in the accuracy of the modeling.

\section{ACKNOWLEDGEMENTS}

We thank the LBA (Large Scale Biosphere Atmosphere in the Amazonia) project, the group of Prof. Humberto Rocha of IAG-USP for providing the data for this work, the anonymous reviewers for suggestions and also the CNPq for the first author's Ph.D. scholarship at IPH / UFRGS (process 140582/2007-0). The last author also thanks CNPq for the financial support their researches.

\section{SUBMISSION STATUS}

Received: 20 may, 2014

Accepted: 21 mar., 2015

\section{CORRESPONDENCE TO}

\section{Adriano Marlison Leão de Sousa}

Instituto Socioambiental e dos Recursos

Hídricos, Universidade Federal Rural da

Amazônia - UFRA, CEP 66073280, Belém, PR, Brasil

e-mail: adriano.souza@ufra.edu.br; marlisoms@yahoo.com.br

\section{REFERENCES}

Agência Nacional de Águas - ANA. Sistema Nacional de Informações sobre Recursos Hídricos. [cited 2013 nov. 23]. Available from: http://www.ana. gov.br/portalsnirh

Andersen J, Dybkjaer KH, Jensen JC, Refsgaard KR, Rasmussen K. Use of remotely sensed precipitation and leaf area index in a distributed hydrological model. Journal of Hydrology 2002; 264(1-4): 34-50. http://dx.doi. org/10.1016/S0022-1694(02)00046-X.

Arnold JG, Williams JR, Srinivasan R, King KW. SWAT: soil and water assessment tool. Temple, TX: USDA-ARS; 1996.

Baldissera GC. Aplicabilidade do modelo de simulação hidrológica SWAT (Soil and Water Assessment Tool), para a bacia hidrográfica do Rio Cuiabá/MT [dissertation]. Cuiabá: Universidade Federal do Mato Grosso; 2005.

Bastiaanssena WGM, Menenti M, Feddes RA, Holtslag AM. A remote sensing surface energy balance algorithm for land (SEBAL). 1. Formulation. Journal of Hydrology 1998; 212-213: 198-212. http://dx.doi.org/10.1016/S00221694(98)00253-4.

Franks SM, Sivapalan KT, Tachikawa Y. Predictions in ungauged basins: international perspectives on the state of the art and pathways forward. Reino Unido: Center for ecology and hydrology; 2005. $348 \mathrm{p}$.

Garcia-Quijano JF, Barros AP. Incorporating canopy physiology into a hydrological model: photosynthesis dynamic respiration, and stomatal sensitivity. Ecological Modelling 2005; 185(1):29-49. http://dx.doi.org/10.1016/j. ecolmodel.2004.08.024.

Gebremichael M, Barros AP. Evolution of modis Gross Primary Productivity (GPP) in tropical monsoon regions. Remote Sensing of Environment 2006; 100(2): 150-166. http://dx.doi.org/10.1016/j.rse.2005.10.009.

Goswami M, O'connor KM, Bhattarai KP. Development of regionalisation procedures using a multi-model approach for flow simulation in an ungauged catchment. Journal of Hydrology 2007; 333(2-4): 517-531. http://dx.doi. org/10.1016/j.jhydrol.2006.09.018.

Immerzeel WW, Droogers P. Calibration of a distributed hydrological model based on satellite evapotranspiration. 
Journal of Hydrology 2008; 349(3-4): 411-424. http:// dx.doi.org/10.1016/j.jhydrol.2007.11.017.

Immerzeel WW, Gaur A, Zwart SJ. Integrating remote sensing and a process-based hydrological model to evaluate water use and productivity in a south indian catchments. Agricultural Water Management 2008; 95(1): 11-24. http:// dx.doi.org/10.1016/j.agwat.2007.08.006.

Kaufman YJ, Justice CO, Flynn LP, Kendall JD, Prins EM, Giglio L et al. Potential global fire monitoring from eosmodis. Journal of Geophysical Research 1998; 103(D24): 32215-32238. http://dx.doi.org/10.1029/98JD01644.

Lévesque E, Anctil F, Van Griensven A, Beauchamp N. Evaluation of streamflow simulation by SWAT model for two small watersheds under snowmelt and rainfall. Hydrological Sciences Journal 2008; 53(5): 961-976. http:// dx.doi.org/10.1623/hysj.53.5.961.

Liew MW, Garbrecht J. Hydrologic simulation of the little washita river experimental watershed using SWAT. Journal of the American Water Resources Association 2003; 39(2): 413-426. http://dx.doi.org/10.1111/j.1752-1688.2003. tb04395.x.

Lubitz E. Avaliação da aplicação do modelo hidrológico SWAT a bacia do Ribeirão Concórdia - Lontras, SC [dissertation]. Blumenau: Universidade Regional de Blumenau; 2009.

Machado RE, Vettorazzi CA, Cruciani DE. Simulação de escoamento em uma microbacia hidrográfica utilizando técnicas de modelagem e geoprocessamento. Revista Brasileira de Recursos Hídricos 2003; 8(1): 147-155.

McMichael CE, Hope AS, Loaiciga HA. Distributed hydrological modeling in california semi-arid shrublands: mike she model calibration and uncertainty estimation. Journal of Hydrology 2006; 317(3-4): 307-324. http:// dx.doi.org/10.1016/j.jhydrol.2005.05.023.

Nash JE, Sutcliffe JV. River flow forecasting through conceptual models. Part I - a discussion of principles. Journal of Hydrology 1970; 10(3): 282-290. http://dx.doi. org/10.1016/0022-1694(70)90255-6.
Oliveira LT. Aplicação do modelo SWAT para simular vazões em uma Bacia Hidrográfica em Aracruz, ES [dissertation]. Jerônimo Monteiro: Programa de PósGraduação em Ciências Florestais, Centro de Ciências Agrárias, Universidade Federal do Espírito Santo; 2014.

Paiva RCD, Paiva EMCD. Simulação hidrológica com modelo SWAT na Bacia Menino Deus I, representativa de mata atlântica. In: Anais do I Simpósio de Recursos Hidricos do Sul e Sudeste; 2006; Curitiba. Curitiba: ABRH; 2006. p. 1-12.

Setegn SG, Srinivasan R, Melesse AM, Dargahi B. SWAT model application and prediction uncertainty analysis in the Lake Tana Basin, Ethiopia. Hydrological Processes 2010; 24: 357-367. http://dx.doi.org/10.1002/hyp.7457.

Sivapalan M, Takeuchi K, Franks SW, Gupta VK, Karambiri $\mathrm{H}$, Lakshmi $\mathrm{V}$ et al. Lahs decade on predictions in ungauged basins (pub), 2003-2012: shaping an exciting future for the hydrological sciences. Hydrological Sciences Journal 2003; 48(6): 857-880. http://dx.doi.org/10.1623/ hysj.48.6.857.51421.

Yildiz O, Barros AP. Elucidating vegetation controls on the hydroclimatology of a mid-latitude basin. Journal of Hydrology 2007; 333(2-4): 431-448. http://dx.doi. org/10.1016/j.jhydrol.2006.09.010.

Zhang YQ, Chiew FHS, Zhang L. Use of remotely sensed actual evapotranspiration to improve rainfall-runoff modeling in southeast australia. Journal of Hydrometeorology 2009; 10(Special Collection): 969-980. http://dx.doi. org/10.1175/2009JHM1061.1.

Zhang YQ, Wegehenkel M. Integration of modis data into a simple model for the spatial distributed simulation of soil water content and evapotranspiration. Remote Sensed Enviroment 2006; 104(4): 393-408. http://dx.doi. org/10.1016/j.rse.2006.05.011. 